\title{
Pengaruh Pemberian Edukasi Terhadap Tingkat Pengetahuan Pasien Rawat Jalan Tentang Penggunaan Antibiotik Di RSUD Kanjuruhan Kabupaten Malang
}

\author{
Wirda Anggraini*, Melisa Rezki Puspitasari, Ria Ramadhani Dwi Atmaja, Hajar Sugihantoro \\ ${ }^{1}$ Jurusan Farmasi, Fakultas Kedokteran dan Ilmu Kesehatan, Universitas Islam Negeri Maulana Malik Ibrahim Malang, \\ Malang, Indonesia
}

INFO ARTIKEL

Sejarah artikel:

Penerimaan

naskah: 3 Agustus

2020

Penerimaan

naskah revisi: 25

Oktober 2020

Disetujui untuk

dipublikasikan: 4

November 2020

Kata kunci :

Antibiotik,

Edukasi, Rawat

Jalan,

Pengetahuan
A B S T R A K

Antibiotik merupakan obat yang berfungsi membunuh dan/atau menghambat pertumbuhan bakteri. Antibiotik termasuk golongan obat keras yang banyak digunakan dalam tata laksana terapi farmakologi. Pengetahuan antibiotik harus digunakan secara rasional dan membutuhkan pengetahuan bagi pasien. Rendahnya tingkat pengetahuan mengenai penggunaan antibiotik dapat menyebabkan penggunaan antibiotik yang tidak tepat, sehingga beresiko menimbulkan efek samping antibiotik. Pemberian edukasi merupakan salah satu cara yang dapat digunakan untuk meningkatkan pengetahuan tentang penggunaan antibiotik secara rasional. Tujuan penelitian ini adalah untuk mengetahui pengaruh edukasi tentang penggunaan antibiotik terhadap pasien rawat jalan di RSUD Kanjuruhan Kabupaten Malang. Jenis penelitian ini adalah Quasi eksperimental menggunakan desain one group pre-test posttest serta pengambilan data secara prospektif dengan menggunakan teknik accidental sampling terhadap 62 responden. Hasil pada penelitian didapatkan, saat pre-test 44 (27 responden) berpengetahuan rendah, 35\% (22 responden) berpengetahuan sedang dan $21 \%$ (13 responden) berpengetahuan tinggi. Pada post-test $3 \%$ ( 2 responden) kategori rendah, 15\% (9 responden) kategori sedang dan 82\% (51 responden) kategori tinggi.Hasil yang diperoleh diuji menggunakan uji T-test yang menunjukkan perbedaan skor antara sebelum dan setelah diberikan edukasi dengan nilai signifikansi 0,00 (pvalue $<0,05$ ). Kesimpulan penelitian ini ialah terdapat pengaruh pemberian edukasi terhadap tingkat pengetahuan pasien rawat jalan di RSUD Kanjuruhan Kabupaten Malang.

\section{The Impact of Eduction Providing on the Level of Knowledge Outpatient Understanding about the Use of Antibiotics in Kanjuruhan Region General Hospital Malang Regency}

Keywords:

Antibiotics,

Education,

Outpatient,

Knowledge

\begin{abstract}
A B S T R A C T
Antibiotics are drugs that work to kill and or inhibit bacterial growth. Antibiotics are a class of prescriptions drugs that are widely used in the management of pharmacological therapy. Antibiotic knowledge must be used rationally and requires knowledge for the patient. Low levels of knowledge about the use of antibiotics can lead to inappropriate use of antibiotics, so there is a risk of causing side effects of antibiotics. Providing education is one way that can be used to increase knowledge about rational use of antibiotics. The aim of this research was to determine the effect of education on the use of antibiotics on outpatients at Kanjuruhan Hospital Malang Regency. This type of research was an Quasi-experimental by using one group pre-test post-test and prospective with sampling using accidental sampling technique data collection of 62 respondents. The result of the research showed that in pre test $44 \%$ respondents were having lack antibiotic-use knowledge, 35\% respondents were having sufficient antibiotic-use knowledge, and $21 \%$ respondents were having good antibiotic-use knowledge. In post-test, 3\% respondents belong to low-category, $15 \%$ respondents belong to medium-category, and $82 \%$ respondents belong to high-category. The T-test showed differences in scores between before and after being given education with a significance value of 0.00 ( $\mathrm{p}$ value $<0.05$ ). The conclusion of this research is that there is an effect of providing education on the level of knowledge of outpatients in Kanjuruhan Hospital Malang Regency.
\end{abstract}




\section{Pendahuluan}

Obat dibagi menjadi beberapa golongan, salah satu golongan obat yang sering digunakan oleh masyarakat ialah obat golonganantibiotik. Antibiotik atau antibiotika adalah golongan senyawa sinstetis atau alami yang mampu dalam menghentikan atau menekan proses biokimia terhadap suatu organisme, khususnya pada proses infeksi bakteri. ${ }^{1}$

Penggunaan antibiotik secara tunggal atau kombinasi di Rumah Sakit negara maju menunjukkan angka $13-37 \%$, sedangkan di negara berkembang menunjukkan angka $30-80 \%$. Hasil penelitian yang dilakukan oleh Antimicrobial Resistence in Indonesia (AMRIN) pada tahun 2000 hingga 2004 menunjukkan terapi penggunaan antibiotik di Rumah Sakit yang cukup tinggi. Penggunaan antbibiotik tanpa indikasi di RSUP Dr Kariadi menunjukkan angka $20-53 \%$ sedangkan, pada terapi antibiotik profilaksis tanpa indikasi sebanyak 43$81 \%$. Berdasarkan data tersebut dapat diketahui penggunaan terapi antibiotik di Rumah Sakit masih tergolong tinggi. ${ }^{2}$

Sebagian besar dari tingginya penggunaan antibiotik terdapat beberapa permasalahan dalam penggunaan antibiotik. Salah satu permasalahan dalam penggunaan antibiotik adalah resistensi antibiotik. Resistensi ialah suatu kondisi bakteri berubah dalam menanggapi antibiotik yang digunakan pada tubuh. Dimana, antibiotik sudah tidak dapat mengganggu aktivitas bakteri didalam tubuh manusia ataupun hewan.

Menurut Krisnata (2018) salah satu faktor penyebab resistensi antibiotik adalah ketidakpatuhan pasien terhadap penggunaan antibiotik itu sendiri. ${ }^{3}$ Menurut Pratiwi (2016) ketidakpatuhan dan ketidakpahaman pasien dalam penggunaan antibiotik menjadi penyebab gagalnya terapi obat antibiotik. ${ }^{4}$ Sedangkan faktor terjadinya penyalahgunaan yang menggunakan antibiotik menurut Dewi ialah kurangnya pengetahuan pasien mengenai antibiotik. ${ }^{5}$

Survei yang dilakukan oleh Center for Indonesian Veterinary Analitical Studies (CIVAS) selama tiga tahun sejak September 2013 hingga Agustus 2016. Pada rumah sakit yang berada di Klaten, Karanganyar dan Kabupaten Sukoharjo menunjukkan bahwa tingkat pengetahuan pasien tentang pengguaan antibiotik pada rumah sakit di daerah tersebut masih rendah, yaitu $61,1 \% .^{6}$

Penelitian yang dilakukan oleh Baroroh menunjukkan peningkatan pengetahuan pasien setelah diberikan edukasi tentang penggunaan antibiotik yaitu meningkat hingga angka 13,8\% dari tingkat pengetahuan sebelum dilakukannya edukasi. Hal ini menunjukan bahwa pemberian edukasi yang baik kepada pasien dapat meningkatkan pemahaman mengenai penggunaan antibiotik sehingga mampu meminimalisir terjadinya kasus resistensi. $^{7}$
Studi Pendahuluan dilakukan oleh peneliti menggunakan kuesioner kepada pasien rawat jalan di ruang tunggu Instalasi Farmasi RSUD Kanjuruhan Kabupaten Malang. Hasil yang didapatkan pada 10 responden menunjukkan bahwa tidak terdapat satupun yang memiliki pengetahuan tentang penggunaan antibiotik secara rasional dengan kategori "tinggi", sedangkan responden dengan kategori "sedang" dan kategori "rendah" masing-masing sebanyak 5 orang $(50 \%)$.

Tujuan dilakukannya penelitian ini ialah agar dapat mengetahui tingkat pengetahuan responden sebelum diberikan edukasi, setelah diberikan edukasi serta untuk mengetahui perbedaan tingkat pengetahuan sebelum dan setelah diberikan edukasi. Penelitian ini memiliki manfaat sebagai sarana informasi megenai penggunaan antibiotik dengan benar kepada responden yang menjadi pasien rawat jalan di RSUD Kanjuruhan Kabupaten Malang.

\section{Metode}

\section{Jenis Penelitian}

Jenis Penelitian yang dilaksanakan adalah penelitian Quasi eksperimental dengan menggunakan desain one group pre-test post-test. Pengambilan data dilakukan secara prospektif dengan pemberian edukasi secara verbal menggunakan media leaflet dan Power Point mengenai penggunaan antibiotik dengan benar untuk mengetahui tingkat pengetahuan pasien rawat jalan tentang penggunaan antibiotik di RSUD Kanjuruhan Kabupaten Malang.

\section{Variabel Penelitian}

Variabel bebas pada penelitian ini ialah pemberian edukasi tentang penggunaan antibiotik secara rasional. Pemberian edukasi diberikan secara langsung kepada responden menggunakan media leaflet serta penjelasan menggunakan Power Point.

\section{Populasi Dan Sampel}

Populasi dalam penelitian ini adalah semua pasien rawat jalan RSUD Kanjuruhan Kabupaten Malang. Sampel yang digunakan pada penelitian ini adalah pasien rawat jalan diruang tunggu instalasi farmasi RSUD Kanjuruhan Kabupaten Malang. Jumlah sampel yang digunakan pada penelitian ini ditentukan menggunakan rumus lameshow sehingga jumlah sampel yang dibutuhkan ialah 62 sebanyak responden.

\section{Metode Pengumpulan Data}

Metode pengambilan sampel yang digunakan pada penelitian ini ialah secara non probabilty sampling dengan teknik accidental sampling yaitu sampel diambil secara kebetulan bertemu dengan peneliti yang memenuhi kriteria penelitian yang berupa pasien rawat jalan di ruang tunggu 
instalasi farmasi RSUD Kanjuruhan Kabupaten Malang.

\section{Analisis Data}

Analisis data statistik pada penelitian ini menggunakan software SPSS versi 24. Analisis yang dilakukan ada beberapa tahap yaitu uji normalitas, uji homogenitas. Jika hasil yang diberikan pada uji normalitas dan uji homogenitas menunjukkan data terdistribusi normal dan homogen maka uji selanjutnya dilakukan uji $T$ test. Jika hasil uji yang dilakukan pada uji normalitas dan uji homogenitas menunjukkan bahwa data tidak terdistribusi secara normal dan tidak homogen maka uji selanjutnya yang dilakukan ialah uji Wilcoxon. Uji $T$ test dan uji wilcoxon dilakukan untuk mengetahui intervensi yang diberikan memiliki pengaruh atau tidak. Sehingga hasil dari analisa uji $T$ test atau uji Wilcoxon dapat menentukan hipotesis pada penelitian ini dapat diterima atau tidak.

\section{Hasil dan Diskusi}

\section{Demografi Responden}

Responden dikategorikan berdasarkan jenis kelamin, usia, pendidikan terakhir dan pekerjaan. Menurut Rahmayanti (2017) perempuan pada umumnya lebih rentan terkena penyakit dan juga lebih cepat ingin mendapatkan penanganan kesehatan oleh tenaga kesehatan apabila mengalami masalah kesehatan dibandingkan dengan lakilaki sehingga ${ }^{8}$ Responden perempuan lebih banyak dari laki-laki, dengan selisih 2 orang (4\%). Usia responden pada penelitian ini didominasi pada kategori lansia (46-65 tahun) yaitu sebanyak 37 responden. Kategori remaja (1225 tahun) menjadi responden paling sedikit pada penelitian ini, yaitu sebanyak 3 responden. Semakin tua usia manusia maka akan semakin memungkinkan untuk mengalami penurunan fungsi tubuh .

Berdasarkan data yang diperoleh, dapat diketahui bahwa pendidikan terakhir paling banyak adalah SD dengan jumlah 28 orang (45\%). Adapun pendidikan terakhir paling sedikit adalah tidak tamat SD yang berjumlah 1 orang (2\%). Menurut Mubarak (2007), tingkat pendidikan yang dimiliki oleh seseorang akan membantu orang tersebut dalam memahami dan memperoleh suatu informasi yang didapat. Semakin tinggi tingkat pendidikan yang dimiliki oleh seseorang maka tingkat pemahaman dalam memperoleh informasi semakin tinggi sehingga dapat menentukan sikap yang benar dalam bertindak. Pendidikan memiliki pengaruh dalam seluruh aspek kehidupan yang ada pada manusia seperti fikiran, perasaan maupun sikapnya. ${ }^{9}$ Selain itu menurut Potter (2005) menyatakan bahwa pendidikan yang dimiliki oleh seorang individu dapat berpengaruh terhadap pengetahuan, sehingga tingkat pendidikan dapat meningkatkan pengetahuan mengenai kesehatan. ${ }^{10}$

\begin{tabular}{lcc}
\hline \multicolumn{1}{c}{ Karakteristik } & $\begin{array}{c}\text { Jumlah } \\
\text { Responden }\end{array}$ & $\begin{array}{c}\text { Persentase } \\
(\%)\end{array}$ \\
Jenis Kelamin & 32 & 52 \\
Perempuan & 30 & 48 \\
Laki-laki & & \\
Usia & 3 & 5 \\
Remaja & 9 & 14 \\
Dewasa & 37 & 60 \\
Lansia & 13 & 21 \\
Manula & & \\
Pendidikan Terakhir & 1 & 1 \\
Tidak tamat SD & 28 & 45 \\
SD & 11 & 18 \\
SMP/MTS & 11 & 18 \\
SMA/SMK/MA & 9 & 15 \\
Sarjana/akademi & 2 & 3 \\
Lain-lain & & \\
Pekerjaan & 16 & 26 \\
Ibu rumah tangga & 17 & 27 \\
Swasta & 3 & 5 \\
PNS & 14 & 23 \\
Wiraswasta & 12 & 19 \\
Lain-lain & & \\
\hline
\end{tabular}

\section{Hasil Kuesioner pre test dan Post test Responden}

Berdasarkan nilai skor yang diperoleh responden, maka tingkat pengetahuan dikelompokkan pada tiga kategori, yaitu rendah $(<55)$, sedang $(55-75)$ dan tinggi $(76-100) . .^{11}$

Tabel 1. Kategori Tingkat Pengetahuan Responden

\begin{tabular}{lcccc}
\hline \multirow{2}{*}{$\begin{array}{l}\text { Tingkat } \\
\text { pengetahuan }\end{array}$} & \multicolumn{2}{c}{ Pre test } & \multicolumn{2}{c}{ Post test } \\
\cline { 2 - 5 } & Jumlah & Persentase & Jumlah & Persentase \\
\hline Rendah & 27 & $44 \%$ & 2 & $3 \%$ \\
Sedang & 22 & $35 \%$ & 9 & $15 \%$ \\
Tinggi & 13 & $21 \%$ & 51 & $82 \%$ \\
\hline Total & $\mathbf{6 2}$ & $\mathbf{1 0 0 \%}$ & $\mathbf{6 2}$ & $\mathbf{1 0 0 \%}$ \\
\hline
\end{tabular}

Tabel 1 menunjukkan perbedaan pengetahuan responden setelah diberikan edukasi. Peningkatan tingkat pengetahuan paling banyak terdapat pada kategori "tinggi", yaitu $13(21 \%)$ responden pada saat pre test dan $51(82 \%)$ responden pada saat Post Test.

Tabel 2. Hasil Kuesioner Pre test dan Post test Responden Penelitian

\begin{tabular}{llllll}
\hline \multirow{2}{*}{ No } & Kuesioner & \multicolumn{2}{c}{ Pre test } & & Post test \\
\cline { 3 - 6 } & Benar & Salah & Benar & Jumlah \\
& $\begin{array}{l}\text { Definisi dan fungsi } \\
\text { antibiotik }\end{array}$ & $25(40 \%)$ & $37(60 \%)$ & $51(82 \%)$ & $11(18 \%)$
\end{tabular}




\begin{tabular}{|c|c|c|c|c|c|c|}
\hline 2 & $\begin{array}{l}\text { Cara penggunaan } \\
\text { antibiotik }\end{array}$ & $17(27 \%)$ & $45(73 \%)$ & $52(84 \%)$ & $10(16 \%)$ & 62 \\
\hline 3 & $\begin{array}{l}\text { Cara mendapatkan } \\
\text { antibiotik }\end{array}$ & $37(60 \%)$ & $25(40 \%)$ & $55(89 \%)$ & $7(11 \%)$ & 62 \\
\hline 4 & $\begin{array}{l}\text { Cara penggunaan } \\
\text { antibiotik }\end{array}$ & $43(69 \%)$ & $19(31 \%)$ & $57(92 \%)$ & $5(8 \%)$ & 62 \\
\hline 5 & Definisi resistensi & $27(44 \%)$ & $35(56 \%)$ & $48(77 \%)$ & $14(23 \%)$ & 62 \\
\hline 6 & $\begin{array}{l}\text { Efek samping } \\
\text { antibiotik }\end{array}$ & $50(81 \%)$ & $12(19 \%)$ & $54(87 \%)$ & $8(13 \%)$ & 62 \\
\hline 7 & $\begin{array}{l}\text { Cara penyimpanan } \\
\text { antibiotik }\end{array}$ & $55(89 \%)$ & $7(11 \%)$ & $57(92 \%)$ & $5(8 \%)$ & 62 \\
\hline 8 & $\begin{array}{l}\text { Cara mendapatkan } \\
\text { antibiotik }\end{array}$ & $48(77 \%)$ & $14(23 \%)$ & $60(97 \%)$ & $2(3 \%)$ & 62 \\
\hline 9 & $\begin{array}{l}\text { Cara mengganti } \\
\text { antibiotik }\end{array}$ & $49(79 \%)$ & $13(21 \%)$ & $57(92 \%)$ & $5(8 \%)$ & 62 \\
\hline 10 & $\begin{array}{l}\text { Cara memusnahkan } \\
\text { antibiotik }\end{array}$ & $17(27 \%)$ & $45(73 \%)$ & $48(77 \%)$ & $14(23 \%)$ & 62 \\
\hline \multicolumn{2}{|c|}{ Rata-rata $(\%)$} & $59 \%$ & $41 \%$ & $87 \%$ & $13 \%$ & \\
\hline
\end{tabular}

Hasil kuesioner yang diperoleh menunjukkan skor rata-rata terendah pada pre test ialah pada indikator cara penggunaan antibiotik $27 \%$ (17 responden) dan cara memusnahkan antibiotik 27\% (17 responden), sedangkan pada post test ialah pada indikator definisi resitensi $77 \%$ (48 responden) dan cara memusnahkan antibiotik $77 \%$ (48 responden). Terdapat peningkatan akan pengetahuan penggunaan antibiotik secara rasional setelah diberikan edukasi. Hal ini sesuai dengan tujuan dilakukannya edukasi menurut Maulana yaitu agar diperoleh peningkatan pengetahuan serta kesadaran pada masyarakat untuk dapat memelihara kesehatannya sendiri. ${ }^{12}$

Kuesioner mengenai definisi antibiotik terdapat pada kuesioner pertama. Hasil yang diperoleh pada pre test sebelum diberikannya edukasi terdapat 25 (40\%) responden yang menjawab benar, selanjutnya pada post test terdapat $51(82 \%)$ responden yang menjawab benar. Sehingga Pada pertanyaan kuesioner pertama ini terjadi peningkatan pengetahuan responden akan definisi dan fungsi dari antibiotik.

Kuesioner mengenai cara penggunaan antibiotik terdapat pada kuesioner kedua dan kuesioner keempat. Kuesioner kedua membahas terkait penggunaan antibiotik yang harus dihabiskan dan kuesioner keempat membahas terkait penggunaan antibiotik yang digunakan harus berdasarkan resep dokter. Hasil yang tunjukan pada kuesioner kedua menunjukkan bahwa pada pre test terdapat 17 pasien yang menjawab benar dengan persentase $27 \%$, selanjutnya pada post test terdapat 52 pasien yang menjawab benar dengan persentase $84 \%$. Selanjutnya pada hasil yang ditunjukkan pada kuesioner keempat menunjukkan bahwa pada pre test terdapat 43 pasien yang menjawab benar dengan persentase $69 \%$, selanjutnya pada post test terdapat 57 pasien yang menjawab benar dengan persentase $92 \%$.

Pengetahuan yang rendah tentang penggunaan antibiotik dapat menyebabkan ketidaktepatan penggunaan antibiotik yang dapat memungkinkan terjadinya resistensi. Penggunaan antibiotik yang benar ialah sesuai dengan anjuran dokter dan harus dihabiskan sesuai jumlah obat yang diberikan pada resep dokter, walaupun gejala

penyakit yang diderita oleh pasien telah sembuh. ${ }^{13}$

Kuesioner yang membahas mengenai cara mendapatkan antibiotik terletak pada kuesioner ketiga dan kuesioner kedelapan. Hasil yang diperoleh pada saat pre test Kuesioner ketiga terdapat 37 pasien yang menjawab benar dengan persentase $60 \%$, selanjutnya pada post test terdapat 55 pasien yang menjawab benar dengan persentase $89 \%$. Sedangkan pada pre test kuesioner kedelapan terdapat 48 pasien yang menjawab benar dengan persentase $77 \%$, selanjutnya pada post test terdapat 60 pasien yang menjawab benar dengan persentase $97 \%$.

Pengetahuan yang rendah tentang cara mendapatkan antibiotik dapat menyebabkan responden mendapatkan informasi tidak tepat mengenai antibiotik. Antibiotik merupakan obat yang termasuk dalam kategori golongan obat keras yang penggunannya harus di bawah instruksi dokter. Salah satu cara meminimalisir kesalahan dalam penggunaan antibiotik ialah dengan memperhatikan cara mendapatkan antibiotik. Cara mendapatkan antibiotik yang baik harus menggunakan resep dokter serta diperoleh dari tempat yang telah memiliki izin resmi untuk mengadakan sediaan antibiotik. Tempat resmi yang yang telah memiliki izin pemerintah tersebut ialah Apotek, Puskesmas, Rumah sakit serta instalasi farmasi yang telah memenuhi ketentuan yang berlaku. ${ }^{13}$

Kuesioner yang berkaitan mengenai definisi resistensi terdapat pada kuesioner kelima. Pada pre test terdapat 27 responden yang menjawab benar dengan persentase $44 \%$, selanjutnya pada post test terdapat 48 responden yang menjawab benar dengan persentase $77 \%$. Sehingga pada pertanyaan kuesioner kelima ini terjadi peningkatan pengetahuan responden akan definisi resistensi antibiotik. Hasil penelitian ini sejalan terhadap penelitian yang dilakukan oleh Putri, yang menyatakan bahwa tingkat pengetahuan responden mengenai definisi resistensi masih tergolong dalam kategori rendah dengan persentase nilai yang benar hanya sebesar $20 \% .^{14}$

Menurut Utami, resistensi ialah kondisi suatu bakteri telah kebal terhadap kerja antibiotik, hal ini menyebabkan antibiotik tidak mampu melawan pertumbuhan dari bakteri tersebut. ${ }^{1}$ Sedangkan menurut 
Tripathi, resistensi adalah suatu keadaan pertumbuhan bakteri sudah tidak terhambat setelah diberikan antibiotik pada dosis normal. ${ }^{15}$. Pertemuan yang diadakan oleh WHO dalam The Review on Antimicrobial Resistance menyatakan pada tahun 2014 angka kematian pasien yang disebabkan oleh resisttensi antibiotik mencapai 700.000 jiwa/tahun sehingga pasien harus memahami makna resistensi dengan baik. ${ }^{20}$

Kuesioner yang membahas terkait efek samping antibiotik terletak pada kuesioner keenam. Pada pre test terdapat 50 pasien yang menjawab benar dengan persentase $81 \%$, selanjutnya pada post test terdapat 54 pasien yang menjawab benar dengan persentase $87 \%$. Sehingga pada kuesioner keenam ini terjadi peningkatan pengetahuan mengenai efek samping antibiotik setelah diberikan edukasi pada responden.

Berdasarkan data yang telah diperoleh menunjukkan bahwa masih terdapat responden yang memiliki pengetahuan yang tidak tepat mengenai efek samping antibiotik. Pengetahuan yang tidak tepat tentang efek samping antibiotik meminimalkan kewaspadaan efek samping antibiotik. Efek samping yang dapat ditimbulkan oleh antibiotik pada umumnya ialah seperti demam, mual, muntah dan sakit perut. ${ }^{16}{ }^{13}$ Sedangkan efek samping antibiotik yang sering mucul menurut Team Medical ialah gangguan sistem pencernaan serta reaksi alergi. Pasien sebaiknya mengetahui efek samping dari antibiotik yang digunakan, hal ini bertujuan agar pasien tidak cemas terhadap efek samping kecil yang diberikan oleh antibiotik serta dapat berkonsultasi dengan dokter jika terjadi efek samping berarti yang di timbulkan oleh antibiotik. ${ }^{17}$

Kuesioner yang membahas terkait cara penyimpanan antibiotik terdapat pada kuesioner ketujuh. Pada pre test terdapat 55 pasien yang menjawab benar dengan persentase $89 \%$, selanjutnya pada post test terdapat 57 pasien yang menjawab benar dengan persentase $92 \%$. Penyimpanan obat pada umumnya disimpan pada tempat yang tertutup rapat pada suhu ruang serta tidak terkena sinar matahari secara langsung. Beberapa jenis obat seperti obat dalam bentuk sediaan tablet dan sirup tidak boleh disimpan pada suhu Freezer maupun pada suhu yang tinggi. Hal ini karena dapat menyebabkan mengganggu stabilitas dan efektifitas dari sediaan obat. ${ }^{18}$

Tindakan mengenai mengganti antibiotik terdapat pada kuesioner kesembilan. Pada pre-test terdapat 49 responden yang menjawab benar dengan persentase $79 \%$, selanjutnya pada post-test terdapat 57 responden yang menjawab benar dengan persentase 92\%. antibiotik merupakan salah satu dari golongan obat keras. Sehingga antibiotik sebagai golongan obat keras harus digunakan atas petunjuk dokter serta tindakan mengganti penggunaan antibiotik harus dibawah instruksi dokter. ${ }^{13}$

Kuesioner yang membahas cara memusnahkan antibiotik terdapat pada kuesioner kesepuluh. Pada pre test terdapat 17 responden yang menjawab benar dengan persentase $27 \%$, selanjutnya pada post test terdapat 48 responden yang menjawab benar dengan persentase $77 \%$. Cara memusnahkan obat yang baik menurut Departemen Kesehatan RI ialah dengan cara melepaskan label dan tutup obat sebelum dibuang pada tempat sampah. Kedua, menggunting kemasan obat. Ketiga, menghancurkan obatobatan dalam bentuk padat serta mengencerkan obat dalam bentuk cair bersama cairan yang tidak dapat dikonsumsi. Hal ini bertujuan agar meminimalisir penyalahgunaan obat oleh oknum yang tidak bertanggungjawab. ${ }^{19}$

\section{Uji Hipotesis}

Uji normalitas dilakukan menggunakan Software SPSS versi 24 dengan uji normalitas Kolmogorov Sminorv, uji normalitas dilakukan agar dapat mengetahui data yang diperoleh berdasarkan penelitian terdistribusi normal atau tidak. Untuk mengetahui data yang di peroleh terdistribusi normal atau tidak dapat diketahui melalui nilai signifikansi dari data tersebut. Berdasarkan uji normalitas yang dilakukan diperoleh nilai signifikansi ialah 0,064. Pada uji normalitas yang menunjukkan bahwa data terdisstribusi secara normal ialah jika nilai signifikansi > 0,05. pada hasil uji normalitas menunjukkan bahwa nilai signifikansi lebih besar dari 0,05 . Hal ini menunjukkan bahwa data yang diperoleh terdistribusi secara normal.

Uji homogenitas dilakukan menggunakan Softwarae SSPSS versi 24, dengan uji Homogenitas Levene. Tujuan dilakukannya uji homogenitas ialah untuk mengetahui keseragaman variasi dari data yang diperoleh pada penelitian. Untuk mengetahui data yang diperoleh homogen atau tidak dapat diketahui berdasarkan nilai signifikansi yang diperoleh pada uji menggunakan Software SPSS. Berdasarkan data hasil uji homogenitas pada Software SPSS versi 24, diperoleh nilai signifikansi 0,020. Pada uji homogenitas, suatu data dikatakan homogen apabila memiliki nilai signifikansi $>0,05$. Pada data yang telah diperoleh berdasarkan data hasil penelitian menunjukkan bahwa nilai signifikansi lebih kecil dari 0,05. Hal ini menunjukkan bahwa data yang diperoleh pada penelitian tidak homogen.

Uji T-test dilakukan menggunakan software SPSS versi 24. Uji T-test dilakukan ketika data penelitian menunjukkan terdistribusi secara normal. Pada uji yang telah dilakukan sebelumnya menunjukkan bahwa data yang diperoleh terdistribusi normal. Sehingga uji selanjutnya yang dilakukan ialah uji Paired Sample T-test. Tujuan dilakukannya uji T-test ialah untuk mengetahui komparasi dua kelompok berpasangan yang membuktikan hipotesis pada penelitian. Dimana, hipotesis pada penelitian ini ialah terdapat pengaruh pengaruh pemberian edukasi terhadap tingkat pengetahuan pasien rawat jalan tentang penggunaan antibiotik secara rasional. Berdasarkan data yang diperoleh pada Uji T-test, maka di peroleh hasil signifikansi 0,00 . Pada uji $T$ test, apabila nilai signifikansi $<0,05$ menunjukkan bahwa hipotesis dapat diterima. Hal ini menunjukkan bahwa pemberian edukasi dapat memberikan pengaruh terhadap tingkat pengetahuan pasien rawat jalan 
tentang penggunaan antibiotik.

Saran yang dapat peneliti berikan kepada pihak RSUD ialah perlu ditingkatkan edukasi yang difokuskan tentang cara penggunaan antibiotik menggunakan media leaflet serta Power point terutama pada pasien yang mendapatkan terapi obat antibiotic. Selain itu, perlu dilakukan penelitian lanjutan mengenai perilaku pasien dalam penggunaan atibiotik dan sebaiknya dilakukan wawancara yang lebih mendalam terhadap responden selain melalui kuesioner.

Berdasarkan penelitian yang telah dilakukan dapat ditarik kesimpulan bahwa Tingkat pengetahuan pasien rawat jalan sebelum diberikan edukasi ialah kategori rendah 44\% (27 responden), sedang 35\% (22 responden) dan tinggi $21 \%$ (13 responden). Tingkat pengetahuan pasien rawat jalan setelah diberikan edukasi ialah kategori rendah 3\% (2 responden), sedang 15\% (9 responden) dan $82 \%$ (51 responden). Terdapat perbedaan tingkat pengetahuan responden sebelum dan setelah diberikan edukasi yang dibuktikan pada hasil uji $T$-Test dengan nilai signifikansi sebesar 0,00 yang mana nilai ini lebih kecil dari 0,05 .

\section{DaftarPustaka}

1. Prapti Utami. Antibiotik Alami Untuk Mengatasi Penyakit. Jakarta Selatan: PT Agromedia Pustaka; 2012.

2. Amrin. Penggunaan Antibiotik di RS Dr Soetomo Surabaya dan dr. Kariardi Semarang. Semarang: Antimicrobial Resistance in Indonesia; 2005

3. I Komang Agus Bayu Krisnata, Nani Parfati, Bobby Presley, Eko Setiawan.Analisis Profil dan Faktor Penyebab Ketidakpatuhan Pengasuh Terhadap Penggunaan Antibiotik Pada Pasien Anak. JMPF. 2018; 1(8):39-50

4. Hening Pratiwi, Nuryanti, Vitis Vini Vera, Warsinah, Nia Kurnia Solihat. Pengaruh Edukasi Terhadap Pengetahuan, Sikap dan Kemampuan Berkomunikasi Atas Informasi Obat. Jurnal Ilmiah Farmasi. 2016; 4(1):10-15

5. Mahardika A. C.Dewi dan Yeni Farida. Tingkat Pengetahuan Pasien Rawat Jalan Tentang Penggunaan Antibiotik di Puskesmas Karanganyar. Journal Pharmaceutical Science and Clinical Research. 2018; (01)27-35

6. Center of Indonesian Veterinary Analytical Studies. Ancaman Resitensi Antimikroba. [Document on the Internet]. Center of Indonesian Veterinary Analytical Studies; $2017 . \quad$ Avaible From: http://civas.net/2017/02/01/ancaman-

resistensiantimikroba.

7. Hanif Nasiatul Baroroh, Esty Dyah Utami, Laksmi Maharani, Ika Mustikaningtias. Peningkatan
Pengetahuan Masyarakat Tentang Penggunaan Antibiotik Bijak dan Rasional. Ad-Dawa Jour.Pharm.Sci. 2018; 1(1)

8. Rahmayanti, T. Karakteristik Responden dalam Penggunaan Jaminan Kesehatan Pada Era BPJS di Puskesmas Cisoka. Tanggerang. 2017.

9. Mubarak, WI. Sebuah Pengantar Proses Belajar Mengajar Dalam Pendidikan. Yogyakarta: Graha Ilmu. 2007.

10. Potter, P.A dan Perry, A. Fundamental Keperawatan edisi 7. Jakarta: Salemba Medika. 2005.

11. Nursalam. Konsep dan Penerapan Metode Penelitian Ilmu Keperawatan. Jakarta: Salemba Medika.2003.

12. Maulana HDJ. Promosi Kesehatan. Jakarta: EGC; 2009

13. Kementrian Kesehatan Republik Indonesia. PERMENKES Nomor 2406/MENKES/PER/2011 Tentang Pedoman Umum Penggunaan Antibiotik. Jakarta: Kementrian Kesehatan Republik Indonesia; 2011

14. Chotimah Kusuma Putri. Evaluasi Tingkat Pengetahuan Masyarakat Tentang Penggunaan Antibiotik di Kabupaten Klaten. Fakultas Farmai. [skripsi]. Surakarta: Universitas Muhammadiyah Surakarta; 2017.

15. Tripathi K.D. Antimicrobial Drug: General Considertion. Essential of Pharmacology: Jaypee Medical Publisher; 2003

16. Kementrian Kesehatan. Konsep Sehat Sakit. Jakarta: Kementrian Kesehatan; 2012.

17. Team medical. Basic Pharmacology and Drug Notes. Makassar: MMM Publishing; 2017

18. The United State Pharmacopeial Convention. The United State of Pharmacopeia (USP) 31th edition. United State: 2008

19. Departemen Kesehatan. Materi Pelatihan dan keterampilan Pengetahuan Memilih Obat Bagi Tenaga Kesehatan.Jakarta: Departemen Kesehatan; 2008

20. Kementrian Kesehatan. Mari Bersama Atasi Resistensi Antimikroba. Departemen Kesehatan RI. 2016. [Diakses 7 mei 2019]. https://www.kemkes.go.id/article/view/16060800002/ mari-bersama-atasi-resistensi-antimikroba-amr-.html 